\title{
Open and Distance Learning (ODL): A Strategy of Development through its Potential Role in Improving Science \& Technology Knowledge
}

\author{
http://dx.doi.org/10.3991/ijet.v10i2.4176 \\ Bharat Inder Fozdar \\ Indira Gandhi National Open University, New Delhi, India
}

\begin{abstract}
Open and distance learning is now seen as a legitimate means through which an effective science and technology education can be disseminated. There are many factors which support this argument. With the advancements of information and communication technologies (ICT), have given rise to new opportunities for sharing information, resources, and experiences, as well as providing networking opportunities with student peers, tutors, and the institution. All these factors suggest that ODL may be the solution for overcoming the gap between those who have had access to science and technology (S\&T) education and those who have not. It is now proven fact that scientific knowledge is a pre-requisite to solve each country's pressing social and economic problem, to transform their societies and to have positive impact on the standards of living and quality of life of the poorest of poor any society. In present situation S\&T capacity building is an indispensable tool for promoting sustainable and inclusive globalization. In the proposed paper, an experience from IGNOU in delivering science programme through ODL mode is shared.
\end{abstract}

Index Terms-information communication technology (ICT), open and distance learning ODL), programme evaluation, quality assessment, science education, science and technology (S\&T) capacity, science technology and innovation (STI).

\section{INTRODUCTION}

It is now an established fact that there is a need to promote Science and Technology (S\&T) for sustained economic growth and improve quality of life. At present whole world is divided into developed and underdeveloping countries. Developed countries produce the overwhelming majority of new scientific and technological knowledge, and they derive great benefit from its use. Underdeveloping countries are struggling, with varying degree of success, to establish scientific and technological research system that improve their economies and provide solution to their social needs. World Bank (2002), in one of its report: 'Strategic Approaches to Science and technology in Development' has reviewed the World Bank's experience in promotions Science and technology (S\&T) capacity and outlined an agenda for action. It noted the following:

"Science and technology have been control in the progress made to date in the fight against poverty and in stimulating economic growth. Today, however, the accelerating rate of progress in science and technology creates both tremendous opportunities and significant risks for developing countries to even access and utilize advances in S\&T has prevented them from capturing the benefit of S\&T that have become commonplace in the rest of the world. To date, the cost to developing countries of low S\&T capacity has been confined mostly to lost opportunities, such as in the failure to capture the benefits of the Green Revolution in Sub-Saharan Africa. In the future, active threats to, inter alia, food safety, nature capital and human health will join lost opportunities in comprising the full costs of inadequate S\&T capacity [1]

In another World Bank's, publication 'Science, Technology and Innovation: Capacity Building for Sustainable Growth and Poverty Reduction' explained and illustrated the role of Science, Technology and Innovation (STI) with detailed case studies [2]. Authors further elaborated the meaning of STI capacity building is about building the technical, vocational engineering, entrepreneurial, managerial and Scientific capacity to solve each country pressing social and economic problem, transform their societies and have positive impact on the standards of living and quality of life of the poorest strata of society. In other words, it is about building the capacity to deliver clean water to rural villages add value to nature resources so that subsistence farmers can generate cash incomes for their families, and help local industries compete in an increasing completive open market. It is concluded that STI capacity building is an indispensable tool for promoting sustainable inclusive globalization.

We can understand the role and importance of STI in development by considering an example of the comparison of economic growth of Korea and any northern African country or even with any other developing country like India from 1960 to 2000. During this period, Korea demonstrated the additional economic growth in comparison to these countries. The high growth in Korea was achieved through investment in STI and knowledge. Forty year ago, the Korea was regarded as one of poorest country. It is now $10^{\text {th }}$ largest economy of the world. Today, 89 percent of Koreans have some degree in tertiary education; this is the highest percentage of any country in the world [3]. Even in 2010 as per the Human Development report 2013, its gross enrolment ratio in tertiary education is 103.9 which still remain highest in the world [4]. As per the Global Competitiveness Report 2012-2013, this country is at $8^{\text {th }}$ placed in providing quality of math and science education [5]

Now, question is why status of S\&T in poor in most of developing countries: like India? Answer is lies in the present status of their education system. In India, present gross enrolment ratio (GER) for tertiary education is $18 \%$ 
and for secondary education is $62 \%$ [6]. India's higher education GER at $18 \%$ is currently well below the global average of $27 \%$. This difference appears more significantly poorer when compared with developed countries such as the US (95\%), Japan (60\%) and the UK (59\%), but also that of developing countries including China $(26 \%)$, Brazil (26\%), Malaysia (23\%) and the Philippines (29\%) [7] [8]. Despite significant progress over the last ten years, Indian Higher education system is still facing three main challenges:

- Supply-demand gap: Currently, over $50 \%$ of Indian population is under 25 years old and by 2020 , India will outplace China as the country with the largest tertiary-age population [9]. As per Twelfth Five Year Plan (2012-2017), by 2020, the Indian government aims to achieve $30 \%$ gross enrolment, which will mean providing 40 million university places, an increase of 14 million in six year. Present education infra-structure could not mange this lode.

- Low quality of teaching and learning: From many years many Indian higher education institutions facing quality issues. Only two Indian higher education brands (IITs and University of Delhi) featured in the QS World University Rankings 2014-15 of the top 500 global universities [10]. The main issues of quality are: a chronic shortage of faculty, poor quality teaching, outdated and rigid curricula and pedagogy, lack of accountability and quality assurance and separation of research and teaching.

- Constraints on research capacity and innovation: With a very low level of $\mathrm{PhD}$ enrolment, India does not have enough high quality researchers; there are few opportunities for interdisciplinary and multidisciplinary working, lack of early stage research experience; a weak supporting system for innovation, and low levels of industry engagement.

Further, at the tertiary level, most new students have gone into liberal education programmes rather than science. The available data of the UGC report 2012 indicate that only $14 \%$ students are in the science stream and $16 \%$ in the area of Engineering and Technology of the total students enrolled for higher education in year 2010-11 [7]. This is far below the USA average of about $35 \%$ enrollment in science related areas. Further, only $1 \%$ of total graduate ultimately enrolled for research programmes [11]. This is partly because of the weak S\&T foundation and poor quality of science education in the developing countries [5].

Beside the challenges discussed for Indian Higher Education earlier, we can list some more factors which may be responsible for weak S\&T growth in the developing countries

- poor enrolment in basic science programme,

- laboratories are generally scare under equipped and obsolete.

- poor status of research facilities.

- very limited funding for research development, and

- lack of job opportunities in the field of research and development.

\section{OPEN AND DistANCE LEARNING (ODL) AND ITS POTENTIAL ROLE IN IMPROVING S\&T}

Open and distance learning is now seen as a legitimate means trough which an effective science and technology education can be provided [12], [13], [14].There are many factors which support this argument. Firstly, it has potential advantages including wider access and cost efficiency. Secondly, its rapid expansion in the past three decades suggests that there exists a ready-made infrastructure which can be capitalized upon to extend science and technology development. Lastly, the more recent advancements in educational technologies like availability of recent generations of information and communication technologies (ICT), have given rise to new opportunities for sharing information, resources, and experiences, as well as providing networking opportunities with student peers, tutors, and the institution of higher education itself. All these factors suggest that ODL may be the solution for overcoming the gap between those who have had access to science education and those who have not. Now lot of data available to support this claims made about it ODL. Now ODL has been used to deliver education at all levels of education. Here, I would like to highlight few potential advantages of ODL

\section{A. Access}

Open and distance learning as a delivery system offers flexible learning on a flexible time scale and provides learners with autonomy in terms of time, technology and material. In addition many ODL institutions have developed policies of 'openness' with regard to entrance re-

TABLE I.

SCIENCE AND TECHNOLOGY: HOW INDIA COMPARES

\begin{tabular}{|l|c|c|c|c|c|}
\hline & $\begin{array}{c}\text { Patents granted } \\
\text { (per million people) }\end{array}$ & $\begin{array}{c}\text { R\&D outlay } \\
\text { (\% of GNP) }\end{array}$ & $\begin{array}{c}\text { Researchers in R\&D (per } \\
\text { million people) }\end{array}$ & $\begin{array}{c}\text { Gross Enrolment ratio } \\
\text { at tertiary level }\end{array}$ & $\begin{array}{c}\text { Tertiary students in science, math } \\
\text { \& engineering (\% of total) }\end{array}$ \\
\hline Australia & 653.7 & 2.3 & 4,258 & 76 & 18.1 \\
\hline United States & 707.6 & 2.8 & 4,673 & 95 & 15.5 \\
\hline Japan & 1759.9 & 3.4 & 5,189 & 60 & 23 \\
\hline South Korea & 1428.8 & 3.4 & 4,946 & 104 & 31.5 \\
\hline UK & 90.2 & 1.8 & 3,794 & 58.5 & 21.7 \\
\hline Germany & 166 & 2.8 & 3,780 & -- & 28.6 \\
\hline Kenya & 0.5 & 0.4 & 56 & 4 & -- \\
\hline China & 100.7 & 1.5 & 1199 & 26 & -- \\
\hline Brazil & 16.7 & 1.1 & 695 & 36 & 12.2 \\
\hline Guatemala & 7.2 & 0.1 & 39.4 & 18 & $\mathbf{1 6}$ \\
\hline India & $\mathbf{5 . 1}$ & $\mathbf{0 . 7}$ & $\mathbf{1 3 6}$ & & -- \\
\hline
\end{tabular}


quirements offering opportunities of learners without access to conventional institutions. Open and distance learning offers opportunities to individuals who are disadvantaged because of their location or gender or economic constraints.

It can deliver education at the 'doorstep' so that learners do not have to physically leave their home environment. This has clear advantages for learners located in remote places where they have few learning opportunities.

\section{B. Cost Efficiency}

Perhaps the strongest selling point for distance education, which has appealed most to education planners in the developing countries, has been its potential to lower costs. These cost advantages arise from the very way through which distance education is organized and delivered- the centralized production of teaching material, the subsequent delivery through media or post, and selective student support. Thus ODL has high fixed costs but low variable costs, which are best taken advantage of when ODL institutions are of sufficient scale and scope. Thus, if ODL institutions are able to capitalize on these economies of scale, they can be cost efficient. ODL may be regarded the best option for the developing countries to improve their post secondary education,

\section{Improving quality}

Where evidence does exist which supports ODL institution role in improving quality is in-service and pre-service training. Here, supplementing existing conventionally delivered material and providing pre-service and inservice training for different professional categories, predominantly teachers, do seem to improve quality. In terms of the latter, much of the evidence is indirect, based on the assumption that better completion rates translate to greater effectiveness [15], [16]. Not only provide increased opportunities for updating, retraining and personal enrichment of teachers, ODL has also established itself in providing quality education through developing high quality learning material using by pooling best resources. Best examples are the quality course materials of UK Open University and Indira Gandhi National Open University (IGNOU).

\section{Educational Technology and ODL}

The use of new technology for educational purposes has always been in the forefront of most cutting-edge open distance learning (ODL) systems. Technology-supported teaching and learning has helped enormously in overcoming the physical distances between teachers and students, enabling the flexible delivery of education at a distance, anyplace, anytime. Keegan viewed the growth of distance education (DE) on the basis of technological developments in information and communication technologies (ICT). According to Keegan, the evaluation in DE is characterized as a move from distance learning (d-Learning), to electronic learning (e-Learning), to mobile learning (mLearning), a phenomenon that he suggests corresponds to the 'societal evolution' from the Industrial Revolution, to the Electronic Revolution of 1980s, to the Mobile Revolution at the close of the 21 st Century [17]. Recent generations of ICTs have given rise to new opportunities for sharing information, resources, and experiences, as well as providing networking opportunities with student peers, tutors, and the institution of higher education itself. The use of these technologies, however, does not necessarily mean the abandonment of the earlier technologies used. In fact, the classic model of DE that uses print along with audio-video remains the most widely used modality in most ODL institutions, especially in developing countries. Indeed, classic DE methods of course delivery still represent the most accessible medium for learning in developing countries. On the other hand, the more flexible and enriching teaching and learning environment afforded by ICT is hard to ignore. Today, the use of mobile devices to enhance ODL systems is starting to take hold. Currently, more and more ODL institutions - particularly in developed countries - are using ICT-supported or ICT- based instruction either as their primary or supplementary delivery system. In a country like India the adoption of ICTbased ODL, such as online instruction, is not yet as popular as in developed countries like USA, Canada, the UK, or Australia. Although it is gradually gaining momentum, impediments such as the high cost of owning personal computers and availability of limited ICT- infrastructure coupled with limited networking capacity still hamper developing countries. There is another communication technology on the horizon, however, one that has tremendous potential - mobile phones, Personal Digital Assistants (PDAs), tablets and smart phones.

Now web base delivery is seen to have the great potential to play. Online learning draws learners together and provides a shared experience, even if the learner is in farflung locations [18], [19], [20]. The rapidly reducing costs associated with mobile phones and palm-top computers have huge implications for delivery of education. Nevertheless, in low-income countries ODL still predominantly uses the print medium for deliver.

\section{1) Role of Open Universities in promoting Science} education:

Many universities word wide now offering science and technology programmes to improve science education and capacity building of human resources through open and distance mode. The perusal of the websites of the prominent Open Universities of the world revealed that 7 out of 15 Open Universities (i.e., about $50 \%$ ), offered undergraduate and postgraduate courses in pure science areas, namely, Physics, Chemistry, Botany and Zoology. Another three Universities offered diverse science-based subjects like nano-biotechnology, environment, and agriculture. Another two universities offered science courses without any lab component. The remaining three universities did not offer any science courses at all. Many of the universities that offered science courses employed ICT tools such as audio/video programmes and online courses for science education. In India, 8 out of 14 State Open Universities, and IGNOU offer undergraduate, postgraduate and doctoral level courses in pure scienc. Three State Open Universities offer courses like Biotechnology, Environmental Sciences, and Nutrition and Dietetics. The remaining three State Open Universities do not offer any science courses. In most of these universities, the lab facilities are provided to the learners through the study centres of the Universities. These study centres are usually conventional colleges in the respective states that have a lab. At IGNOU, science education at a distance is being offered through its School of Sciences for more than 20 years and every year 5000 to 6000 students were admitted in under graduate programmes. 


\section{2) About IGNOU's B.Sc. Programme}

In this section, we will briefly outline the teaching and learning model used in IGNOU's Bachelor's Degree (B.Sc.) programme. IGNOU offers a B.Sc. in various science disciplines such as Chemistry, Physics, Mathematics, Botany, and Zoology. Two important objectives of the B.Sc. programme are to provide higher educational opportunities to those who may have missed out on formal education (i.e., working persons, people living in rural or remote areas, housewives, and the disadvantaged). To complete the B.Sc. programme either as general or major in any of the science disciplines on offer at IGNOU, learners must earn 96 credits (one credit equal to approximately 30 hours of learning activity), out of which 24 credits must be devoted to foundation courses, and eight to 16 credits to applied courses. The remaining 56 to 64 credits are subject-specific. It takes students a minimum of three years to complete IGNOU's B.Sc. programme. The maximum limit of completion of the programme is six years. At IGNOU, students are permitted to study at their own pace in within the maximum period.

\section{3) Delivery Mechanism}

The methodology of instruction of IGNOU is different from that followed in the conventional system. Most of the instructions are imparted through distance rather than face-to-face communication as is true of any distance education institution. However the system at IGNOU is more learners oriented and the student is an active participant in the teaching-learning process. A multimedia approach is followed for instruction. Besides the self instructional printed materials both for theory and practical courses, other means of imparting education are audio and video cassettes/CDs (these are available at study centres only), audio-video programmes transmitted through the National Network of Doordarshan and All India Radio (selected station), face-to-face counseling at study centres by academic counsellors, assignments, laboratory work, teleconferencing, interactive radio counseling and video programmes through National and Gyan Darshan Channels.

EDUSAT a satellite dedicated to education purposes has also been made available to IGNOU. Science faculty is presently using EDUSAT for the tele-counseling of both theory and lab courses. With the increased availability of new educational technologies, distance educators have got the opportunity to design laboratory based science courses which could provide their students with a wider range of learning aids such as radio and TV channels, internet, computer-aided learning, local area networking and computer simulation to support teaching in laboratories [21], [22].

Never the less, face to face counseling sessions are very important tools for the guidance and problem solving in the overall teaching learning process. However, it is not compulsory for IGNOU students to attend the counseling sessions for theory courses.

In our view good laboratory component is essential to the overall success and credibility of any undergraduate science programme or in general any science programme. Distance education institutions are offering laboratory courses by three modes. In first mode the laboratory is conducted at home using home-study kits [23], [24]. In second mode experiments are conducted on weekends throughout the year and in the third mode lab courses are conducted in concentrated laboratory session for a weeklong. These practices are followed by a number of distance education institutions [25], [26]. At IGNOU we are following both weeklong and in some cases weekend approaches. The laboratory courses are conducted at study centres scattered all over India during summer and autumn vacations, so that in-service persons can attend laboratory courses without difficulty. The laboratory component is delivered through innovatively designed laboratory courses. These courses are worth 2 or 4 credits. A 2 credit laboratory course requires full-time presence of the learner at the study centre for 7 days continuously. During this time a learner has to work for around $60 \mathrm{hrs}$. Around 40 hours are spent on experimental practical work and remaining time is used for doing calculations, preparation of records, viewing or listening to the video/audio programmes. Unlike theory counseling attendance in the laboratory courses is compulsory.

Every experiment is evaluated daily and $70 \%$ weightage is given to this continues assessment; this is unlike the theory courses where weightage is only $30 \%$. For theory courses term end examination carries $70 \%$ weightage in the final result. For laboratory courses, assigned experiment, which is unguided, is like a term end exam in case of theory courses and carries $30 \%$ weightage. In order to optimize the time available for laboratory work well designed laboratory manuals, counsellor's manuals and in some cases video programmes are provided. Lab manuals contain complete details of experiments and methods of taking observations and calculations. Counsellor's manual provides details of activities to be performed by counsellors with respect to conduct of a laboratory course. As per the instructions of counsellor's manual the counsellor carries out pre-lab preparations before the start of lab session, so that she /he is left with sufficient time to guide learners through the lab sessions. As mentioned earlier some laboratory courses are well supplemented with video programmes. These programmes further reduce the demonstration time of the counsellors. It has been observed from the students' examination records that their performance in the laboratory courses of IGNOU is very good. This may be attributed to the following:

- the laboratory courses are performed under direct guidance of the counselors in face to face situation, and

- preparation prior to attending lab sessions and instant feedback [27].

In our view besides these factors, other factors, which also have a role to play in the good performance of learners in laboratory courses, are well-designed laboratory manuals, counsellor's manual, and more weight age of continuous assessment (70\%).

\section{SURVEY STUDY}

\section{A. Aims of Study}

The main aims of this study was to develop a programme evaluation instrument that can address the unique aspects of ODL science programme and carry out a feedback survey using developed instrument in order to:

- understand the profile of undergraduate science learners;

- assess the adequacy and efficiency and usefulness of the print material; 
- evaluate the accessibility of the print material in terms of presentation style, difficulty level, etc.;

- asses the role of continuous assessment in improving learning and achieving learning outcomes;

- assess the effectiveness of counselling sessions and multimedia components and their role in improving learning;

- evaluate the efficiency and success of the student support services;

- assess the overall quality and effectiveness of laboratory component;

- ascertain the overall quality of course material, student support services, and multimedia support in the B.Sc. programme.

- suggest different mechanisms to improve overall teaching and learning environment of B.Sc. learners on the basis of feedback data.

\section{B. Analysis of feedback data:Evaluating B.Sc.}

\section{Programme}

Development of Evaluation Instrument:

After reviewing literature we found four step process followed by Roberts et al. for the development of evaluation instrument particularly appropriate for our study [28]. Roberts et al. basically adapted the procedure used by Biner [29]. In this study, steps were slightly modified as per our requirements. In step 3 we have used factor analysis for selecting essential Items (see Figure 1).

\begin{tabular}{|c|c|c|c|}
\hline $\begin{array}{l}\text { Step 1: } \\
\text { Generating } \\
\text { individual } \\
\text { items } \\
\text { related to } \\
\text { programm } \\
\text { e issues }\end{array}$ & $\begin{array}{l}\text { Step 2: } \\
\text { Categoriza } \\
\text { tion of } \\
\text { Items in } \\
\text { groups }\end{array}$ & $\begin{array}{l}\text { Step 3: } \\
\text { Selecting } \\
\text { Essential } \\
\text { Items } \\
\text { using } \\
\text { factor } \\
\text { analysis }\end{array}$ & $\begin{array}{l}\text { Step 4: } \\
\text { Finalisatio } \\
\mathrm{n} \text { of } \\
\text { Instrument }\end{array}$ \\
\hline
\end{tabular}

Figure 1.

With the help of experts and learners we have identified as many items as possible related to effectiveness, quality and satisfaction with different components of the programme like course material, audio-video support, student support as study centre, course assessment procedures, and laboratory component related issues. We grouped the identified items in several groups like A: Profile, B: Print material, C: Counselling, D: Audio/Video/TV/EDUSAT/IRC, E: Student support service, F: General and G: Lab component. This first draft of the instrument was administered to randomly selected 110 B.Sc. learners during their laboratory sessions. Collected data from the pilot test was used for caring out factor analysis to reduce the size of the questionnaire so that an effective instrument may be developed for collecting feedback from learners.

The final questionnaires were administered on the learners who took admission in the third year of B.Sc. programme in year 2006, 2007 and 2008. We consider that these learners had sufficient exposure to our B.Sc. programme. Total number of students enrolled in the third years about 4000 . Out of 4000 students, a random sample of 1000 students (keeping in mind the geographical distribution) was identified and the questionnaires were mailed to them by post. A total of 326 responses were received with a response rate of $32.6 \%$. The feedback data analysis was carried out mainly by calculating the percentages, standard deviation (SD) and mean for the items.

\section{1) Respondents' profile}

The demographic characteristics of sample are shown in Table 1. Out of 326 respondents $42.6 \%$ were female and $57.4 \%$ male. Almost $78.5 \%$ of respondents were in the age group of 19-25 and mainly from urban background $(73.9 \%)$. Regarding social status, about $69.9 \%$ respondents were from general category and $19.9 \%$ from OBC, $5.2 \%$ from ST and $4.6 \%$ from SC categories, respectively. Our $73.6 \%$ respondents were of urban back ground and 25.8 from rural background. Regarding their marital status, about $83.7 \%$ were unmarried and $16.3 \%$ married. Average monthly family income of most of the learners was either less than 10,000 or between $10,000-20,000$ $(72.1 \%)$. Good number of respondents were living very far away from the study centres i.e. $(>20 \mathrm{~km})$ from the study centres $(33.9 \%)$; thus they had to spend good time to reach their study centres. Only very few $(8.3 \%)$ had completed an open/distance programme before joining IGNOU B.Sc.

TABLE II

DEMOGRAPHIC CHARACTERISTICS OF PARTICIPANTS

\begin{tabular}{|c|c|c|}
\hline & $\mathbf{N}(326)$ & Percentage \\
\hline \multicolumn{3}{|l|}{ Sex } \\
\hline Male & 187 & 57.4 \\
\hline Female & 139 & 42.6 \\
\hline \multicolumn{3}{|l|}{ Geographical } \\
\hline Distribution & & \\
\hline Urban & 241 & $73.9 \backslash$ \\
\hline Rural & 85 & 26.1 \\
\hline \multicolumn{3}{|l|}{ Age Group } \\
\hline $19-25$ & 256 & 78.5 \\
\hline $26-35$ & 53 & 16.3 \\
\hline $36-45$ & 11 & 3.4 \\
\hline$>45$ & 3 & 0.9 \\
\hline \multicolumn{3}{|l|}{ Marital Status } \\
\hline Married & 53 & 16.3 \\
\hline Unmarried & 273 & 83.7 \\
\hline \multicolumn{3}{|l|}{ Occupation* } \\
\hline Employed & 144 & 44.2 \\
\hline Unemployed & 172 & 52.8 \\
\hline \multicolumn{3}{|l|}{$\begin{array}{l}\text { Average monthly } \\
\text { income* }\end{array}$} \\
\hline$>10,000$ & 135 & 41.4 \\
\hline $10,000-20,000$ & 100 & 30.7 \\
\hline $20,000-30,000$ & 38 & 11.7 \\
\hline above 30,000 & 47 & 14.4 \\
\hline
\end{tabular}

In response to reason for joining B.Sc. programme of IGNOU, majority of learner answered that they had joined B.Sc. programme to improve job prospects and to get a Bachelor's degree in area of science $(62 \%)$. In response to reason for studying B.Sc. (Major), majority of learners chose the option of keen interest in particular subject and a desire to pursue higher studies in that area $(80 \%)$.

Most of our respondents had internet access $(71.2 \%)$. Though, only about $32 \%$ at home and $46 \%$ were accessing from cyber cafe. The purpose of this question was to investigate the availability of internet facility. This would 
help us to know the possibility of ICT based alternative approaches for teaching, besides the classical mode of ODL, which is mainly employed in IGNOU presently.

Survey results indicated that learners are highly satisfied with the print components and they rated it to be of high quality, relevant and useful. They liked all the features of self instructional course like programme/course objectives, understandable and lucid language, self assessment questions (SAQs), terminal questions (TQs), worthwhile exercises/examples and illustrations to enhance understanding of the subject, summary, assignments, etc. Majority do not require any additional books. Only $23.3 \%$ respondents have some work load related problem and problems in managing various aspects of assignment components like late receipt of assignments, no timely reflection of marks in award list etc. Regarding counselling sessions conducted at the study centres, on the basis of survey results it can be concluded that counselling is conducted effectively at IGNOU study centres and it is very useful clarifying the doubts and in removing difficulty. Majority of learners also suggested that the number of counselling sessions were not enough as most of the science courses had difficult concepts.

In B.Sc. programme though print and counselling support are the main components of teaching process, but these components are also supplemented with multimedia support like audio, video, TV, EDUSAT, web support and IRC. In this part we assess to how effectively these are being used by our learners. Data analysis of survey results indicates that majority of learners are not availing these facilities. Only 28.5 respondents came across with these multimedia components. However, about 53.4 have shown interest in internet/web-based counselling activity. The main problem with the multimedia support is of access. Though IGNOU provides support for watching EDUSAT and video at study centres but because of administrative reasons, technical reasons or time constraint learners could not get the benefit of this facility most of time. Now we have to look at other alternatives like internet/web based supports which are becoming more accessible to our learners.

Survey results regarding student support services indicate that in majority the B.Sc. learners were satisfied with the overall facilities provided to learners at the study centres. There were some issues related to library facility, EDUSAT facility, teleconferencing facility, and facilities of listening audio, watching video and overall administrative support.

Survey results regarding term end examination clearly indicated that there is urgent need for timely declaration of term end result so that learners have a clear picture of their remaining credits to be cleared. Response to question 'Would you recommend to others to study B.Sc.through IGNOU? was quite encouraging (69\% positive response). This clearly indicates that learners are highly satisfied with the academic and largely with the administrative support available to them.

Laboratory work has special role in enhancing teaching and learning environment of a science programme. Many educators have explained the purpose and value of lab work as a learning strategy in science education. Ross and Scanlon summarized the aims of lab work into following four groups:
1. Training in technique (psychomotor, observation, data handling),

2. learning basic ideas of the subject,

3. learning how to do research, and

4. motivate through interest [30].

Our survey findings clearly indicate that laboratory work at IGNOU is justifing its role and IGNOU is able to provide quality science education through its high quality of laboratory support. Regarding learner opinion on the conduct of laboratory courses, majority of students are satisfied with the facility available at study centre, the help from counsellors, and evaluation system in place. Learners are not happy with the video support available at study centres, so there is a need of providing better ICT support for further enhancing learning from laboratory work.

\section{CONCLUSION AND RECOMMENDATIONS}

Our main findings are based on the data collected from 326 respondents from a randomly chosen sample of 1000 learners across India. The method employed for the study is a survey study using a unique instrument which was developed on the basis of factor analysis of the data obtained from a pilot study. Feedback study result indicated that course material in the form of print is of high quality, relevant and very useful. Continuous assessment component in the form of self assessment questions, terminal question and assignment is very useful in the preparation for term- end examination. A good number of B.Sc. learners could not attend counselling session because of distance of study centre from their habitation and state of their employment. They also suggested that there should be more counselling sessions than the present number considering difficulty level of science courses. Learners were not much satisfied with the administrative support available at study centres but they found adequate laboratory support available for conducting laboratory courses. However, there is a need for overall improvement in administrative support and need to provide better access to multimedia component to our B.Sc. learners. Internet/web based approach for multimedia will be a better alternative as about $71.1 \%$ our learners can access internet. These findings are further supported by the data we collected for overall quality of some important components of the B.Sc. programme.

\section{A. Overall quality of the components of B.Sc. programme}

Data of Table 2 and Figure 1 clearly indicates that the satisfaction mean for most of the items was high (above 3 ) and almost all standard deviations were less than 1.00 or around one. These indicated that most of the respondents had common thought in terms of the indicators listed in Table 2. Comparatively low mean for item no. 4 regarding quality of multimedia support with B.Sc. programme indicates that this component is not implemented properly or B.Sc. learners could not utilize this facility because of reasons discussed earlier. Among all the components listed in Table 2, learners rated the course material to be of high quality (mean 4.2). Therefore, it can be concluded that IGNOU has succeeded in providing access to higher quality science education to a diverse learner -population across the country. 
PAPER

Open AND Distance LeARning (ODL): A STRATEGy OF DEVElopment THROUGH its Potential Role IN...

TABLE III.

FREQUENCY, PERCENTAGE AND MEAN OF LEARNERS' SATISFACTION FOR THE ITEMS RELATED TO OVERALL QUALITY OF THE DIFFERENT COMPONENTS OF B.SC. PROGRAMME

\begin{tabular}{|c|c|c|c|c|c|c|c|c|}
\hline Statement & Mean & SD & Excellent & Good & Average & Poor & Very oor & Missing \\
\hline & & & 5 & 4 & 3 & 2 & 1 & \\
\hline Quality of course material & 4.2 & 0.79 & $44(44.9)$ & $38(38.8)$ & $2(2.0)$ & $8(8.2)$ & $00(0.0)$ & 6 \\
\hline Quality of student support at Study Centre & 3.6 & 0.95 & $34(34.7)$ & $46(46.9)$ & $8(8.2)$ & $00(0.0)$ & $4(4.1)$ & 6 \\
\hline Quality of student support at Regional centre/ HQ & 3.4 & 1.11 & $30(30.6)$ & $38(38.8)$ & $14(14.3)$ & $6(6.1)$ & $6(6.1)$ & 4 \\
\hline Quality of multimedia support with BSc programme & 3.1 & 1.15 & $48(49)$ & $28(28.6)$ & $8(8.2)$ & $4(4.1)$ & $00(0.0)$ & 10 \\
\hline
\end{tabular}

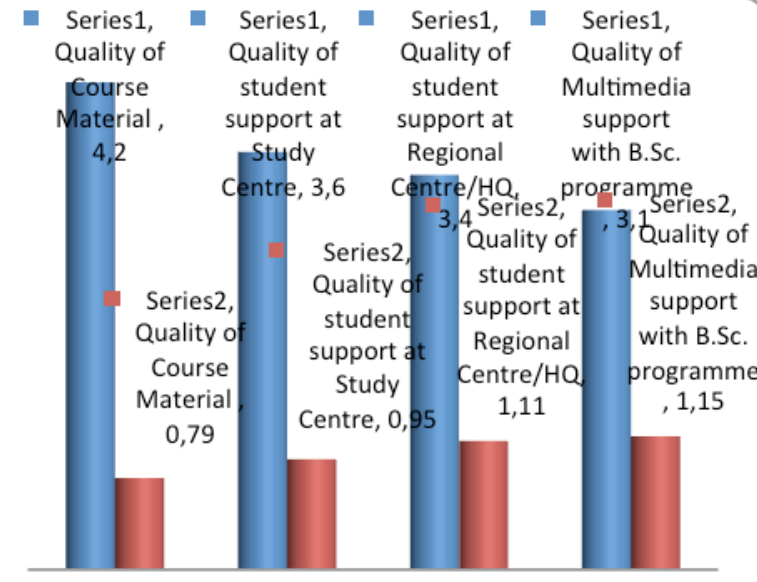

Figure 2. Mean (blue column) and SD (red column) values for of learners' satisfaction for the items mentioned in Table 10 related to overall quality of the different components of B.Sc. Programme.

Results of this study indicate that IGNOU University has succeeded in providing access to higher science education to a diverse learner population across the country. The success rates, retention rates, and performances of learners are also important evaluation tools they are indicators of the acceptability and sustainability of a programme. As reported earlier by Fozdar and Kumar; and Mishra at al. on the basis of registration pattern of last ten years about $30 \%$ learners reach to third level of the B.Sc. programe [12], [14]. Thus, the major problem of retention rate which is not very good in the B.Sc. Programme. If we look at the pass out rate we arrived at the same conclusion that pass our rate again is very poor, it is about. In IGNOU situation, It is little difficult to measure pass out rate as we allow our student for six years to complete the programme and after the completion of six years, they can also again take re-admission for another two years. A rough estimation can be made on the basis of average admissions and average pass out, it is about $20 \%$. Any way it is not at all satisfactory. These both issues of dropout and poor completion rate can be well address in ODL systems by following effective management [31], designing and implementing interventions at anticipate stages that students tend to drop-out, and pre-empt such decisions [32].

Like other developing countries, in India, college and university graduates don't pursue careers - in effect research in sciences. The main reasons for this is poor investments by the Government and private players in the S\&T education sector; university and college labs are generally under-equipped, overcrowded and poorly staffed; experiments and demonstrations are few. All these have a snowball effect: low standards at the undergrad level are reflected among entrants into postgraduate education and research. In such situation IGNOU's experience suggested that more flexible and cost effective ODL system is the best solution to provide quality science education using new education technologies to large number of students.

\section{REFERENCES}

[1] World Bank,. "How Korean Firms Use Knowledge.” World Bank, Washington, DC., 2002.

[2] Watkins, Alfred J. And Ehst, Michael, Science, technology, and innovation : capacity building for sustainable growth and poverty reduction. World Bank, Washington, D.C., (2008). http://dx.doi.org/10.1596/978-0-8213-7380-4

[3] Wolfowitz, P.,Key Note Speech, Global Forum: World Banck, Washington, DC. 2007.

[4] Malik Khalid, The Rise of the South: Human Progress in a Diverse World, Human Development Report 2013, UNDP, 2013.

[5] Schwab Klaus, The Global Competitiveness Report 2012-2013, World Economic Forum, 2012.

[6] Educational Statistic at a Glance, HRD Ministry Report, India, 2011.

[7] Ernst and Young. Higher Education in India: Twelfth Five Year Plan (2012-2017) and beyond, FICCI Higher Education Summit 2012, Ernst \& Young Pvt Ltd, Planning Commission Government of India, 2012.

[8] Global Education Digest Opportunities lost: The impact of grade repetition and early school leaving, UNESCO Institute for Statistics, Canada, 2012.

[9] British Council Understanding India: The future of higher education and opportunities for international cooperation, British Council India, 2014

[10] QS world university rankings, 2014. Retrieve on 15 September, 2014 from http://www.topuniversities.com/qs-world-universityrankings.

[11] UGC Report: Higher Educationin India at a glance, UGC, India, 2012

[12] Fozdar, B. I., and Kumar, L. S., Teaching Chemistry at Indira Gandhi National Open University. Turkish Online Journal of Distance Education, 7(2), 2006, pp80-89.

[13] Kumar, L. and Fozdar, B. I., Course Evaluation: A Holistic Approach: Evaluation, Indian Journal of Open Learning, 2007, 16(2), 2009. Pp. 113-128.

[14] Mishra, A., Vijayshri and Garg S., Evaluation of the undergraduate Physics Programme at Indira Gandhi National Open University: A Case Study, International Review of Research in Open and Distance Learning, 10(6), 2009, pp.106-123.

[15] Perraton, H, Models for Open and Distance Learning 1: Teacher Education and Training. International Research Foundation for Open Learning and The Commonwealth of Learning,2003.

[16] Fozdar, B. I. , Kumar, L. And Saxena A., In-Service Teacher Training Programme: An Analysis of Learner Opinion on the Effectiveness of The Programme, Malaysian Journal of Distance Education 9(2), 2007, pp. 65-87.

[17] Keegan, D., The Future of Learning: From e-learning to $\mathrm{m}$ learning (No. ZIFF Papiere 119, Hagen Zentrales Institute fur Fernstudienforschung: FernUniversitat, 2002.

[18] Knight, P., Promoting retention and successful completion on Masters course in education: a study comparing e-tuition using 
PAPER

Open AND Distance LeARning (ODL): A STRATEGy OF DEVElopment through its Potential Role in...

asynchronous conferencing software with face-to-face tuition. Open Learning, 22(1), 2007. Pp. 87-96. http://dx.doi.org/10.1080/02680510601100184

[19] Rovai, A.P. and Barnum, K.T., On-line course effectiveness: an analysis of student interactions and perceptions of learning. Journal of Distance Education, 18(1) 2003, pp. 57-73.

[20] Swan, K., Online collaboration: Introduction to the special issue. Journal of Asynchronous Learning Networking, 10 (1), 2006.

[21] Kannepolh, D., Using Computer Simulation to Supplement Teaching Laboratories in Chemistry for Distance Delivery, Journal of Distance Education, 16(2), 2001, 58-65.

[22] Kahveci, A., Chemistry at a Distance: Instructional Strategies and the Internet Component of the Course - A Chronological Review of the Literature. Turkish Online Journal of Distance EducationTOJDE, 4(3), 2003.

[23] Bennett, S., Opening up Science: the Teaching of Science at the Open University, UK. Paper presented at the 17th ICDE Conference, Birmingham, UK. 1995.

[24] Kennepohl. D., Home Study Micro labs, Journal of Chemical Education, 75, 1996, 938-39.

[25] Kennepohl, D \& Last, A.,Teaching Chemistry at Canada Open University, Distance Education, 21(1), 2000, 183-197. http://dx.doi.org/10.1080/0158791000210111

[26] Koshy, K, Bonato, J, and Faasalanina T., Chemistry Through Distance Teaching: A South Pacific Experiment, Distance Education, 15(2), 1994, 291-299. http://dx.doi.org/10.1080/ 0158791940150208

[27] Khare, P, Sexena, A, and Garg, S., Knowledge Discoveries on Performance of IGNOU Graduates Through Data Mining, Indian Journal of Open Learning, 12(1), 2003, 29-45.
[28] Roberts, T.G., Irani, T.A., Tely, T.W. \& Lundy, L.K., The development of an instrument to evaluate distance education course using student attitudes, The American Journal of Distance Education, 19(1), 2005, pp. 51-64. http://dx.doi.org/10.1207/s15389286ajde1901_5

[29] Biner, P.M., The development of an instrument to measure student attitude toward televised courses. The American Journal of Distance Education, 7(1), pp. 1993, 62-73.

[30] Ross, S and Scanlon, Open Science: the distance teaching and open learning of science subjects, Paul Chapman Publishing, 1995.

[31] Woodley, A., Delange, P.,and Tanewski, G., Student progress in distance education: Kenber's model re-visited. Open Learning, 16(2), 2001, pp. 113-131 http://dx.doi.org/10.1080/02680 $\underline{510123105}$

[32] Sampson,O., The impact on retention of intervention to support distance-learning students. Open Learning, 19(1), 2004, pp. 78-95 http://dx.doi.org/10.1080/0268051042000177863

\section{AUTHORS}

Bharat Inder Fozdar is with the Indira Gandgi National Open University, New Delhi, 110068 India (e-mail: bifozdar@ignou.ac.in).

This article is an extended and modified version of a paper presented at the International GUIDE Conference, held at Universidad Panamericana, Guatemala, April 2014. Submitted 26 September 2014. Published as resubmitted by the author 24 March 2015. 